Syntax Literate : Jurnal Ilmiah Indonesia p-ISSN: 2541-0849 e-ISSN: 2548-1398

Vol. 5, No. 6, Juni 2020

\title{
PENINGKATAN KESEGARAN JASMANI MELALUI PELATIHAN AEROBIK DENGAN BEBAN DIBANDINGKAN TANPA BEBAN PADA ANGGOTA MILITER PUSDIKJAS TNI AD DI CIMAHI
}

\author{
Ahmad Dwi Marwiyanto \\ Akademi Fisioterapi RS. Dustira Cimahi \\ Email: fisiioahmad@gmai.com
}

\section{Abstract}

This study to detect differences in aerobic exercise without the burden and the burden of the increase value of VO2 max. Both groups of both control and treatment groups did run aerobics for 30 minutes 5 times per week for 10 weeks. To further see the VO2 max values changes between initial and final value in both groups by doing a test run in 12 minutes. Independent T-test was used to compare changes in VO2 max values between groups. Of the 34 physical education centre military member of the Army in Cimahi are divided into 2 groups: control and treatment group results (1) There is an increase in VO2 max value in the control group between before and after doing aerobic with no load ( $p<0.05)$. (2) There is increase in VO2 max in the treatment group between before and after running aerobics with weight $(p<0.05)$. (3) There was no significant difference between the two groups to increase VO2 max value before and after aerobic run ( $p>0.05$ ). From these results it can be concluded that the use of load weighing $5.5 \mathrm{~kg}$ at the back by doing aerobic running 5 times a week for 10 weeks there was no effect on increased value of VO2 max in physical education centre of Army military members the postscript of people who have been trained or have VO2 max value of a good start. The results of this study is expected to be a basis for further research to develop a program of aerobic exercise in improving physical fitness.

Keywords: VO2 max, aerobic exercise and the military

\section{Abstrak}

Penelitian ini dimaksudkan untuk membentuk pelatihan alternative yaitu penambahan beban pada latihan aerobik pada anggota Pusdikjas TNI AD di Cimahi dalam meningkatkan kesegaran jasmani. Kesegaran jasmani merupakan kemampuan seseorang untuk melakukan suatu pekerjaan tertentu dengan baik, tanpa mengalami kelelahan yang berarti. Pengukuran kesegaran jasmani dengan mengetahui VO2 maks dipandang sebagai cara yang paling baik dan dipercayai memiliki hubungan dengan kesehatan, prestasi kerja dan olahraga, semua ini berkaitan dengan daya tahan dan perfoma. Penelitian ini untuk mengetahui adanya perbedaan latihan aerobik tanpa beban dan dengan beban terhadap peningkatan nilai VO2 maks. Kedua kelompok baik kelompok kontrol maupun perlakuan melakukan lari aerobik selama 30 menit 5 kali perminggu selama 10 minggu. Untuk selanjutnya dilihat perubahan nilai VO2 maks Antara nilai awal dan akhir pada kedua kelompok dengan melakukan tes lari 12 menit. Uji T- independent 
digunakan untuk membandingkan perubahan nilai VO2 maks antar kelompok. Dari 34 orang anggota militer Pusdikjas TNI AD di Cimahi yang terbagi 2 kelompok, yaitu kelompok kontrol dan perlakuan didapatkan hasil (1) Terdapat peningkatan nilai VO2 maks pada kelompok kontrol antara sebelum dan sesudah melakukan lari aerobic tanpa beban $(\mathrm{p}<0,05)$. (2) Ada perbedaan peningkatan nilai VO2 maks pada kelompok perlakuan antara sebelum dan sesudah melakukan lari aerobik dengan beban $(\mathrm{p}<0,05)$. (3) Tidak ada perbedaan yang signifikan antara kedua kelompok terhadap peningkatan nilai VO2 maks sebelum dan sesudah melakukan lari aerobik ( $p>0,05)$. Dari hasil ini dapat disimpulkan bahwa penggunaan beban seberat $5,5 \mathrm{~kg}$ di punggung dengan melakukan lari aerobik 5 kali seminggu selama 10 minggu tidak ada pengaruh terhadap peningkatan nilai VO2 maks pada anggota militer TNI AD Pusdikjas yang merupakan orang-orang yang sudah terlatih atau mempunyai nilai VO2 maks awal baik. Hasil penelitian ini diharapkan dapat dipakai dasar penelitian lebih lanjut untuk mengembangkan program latihan aerobik dalam meningkatkan kesegaran jasmani.

Kata kunci : VO2 maks, latihan aerobik dan militer.

\section{Pendahuluan}

Kemajuan bangsa pada era globalisasi menuntut adanya penguasaan ilmu pengetahuan dan teknologi serta didukung tersedianya sumber daya manusia (SDM) yang handal. Bangsa yang tidak menguasai ilmu pengetahuan dan teknologi atau tertinggal dalam bidang ini akan terlibat dalam percaturan antarbangsa yang sangat kompetitif (Kusnaendar, 2018).

Tentara Nasional Indonesia Angkatan Darat (TNI AD) memiliki tugas pokok yang sangat berat yaitu menegakkan kedaulatan negara dan keutuhan wilayah darat negara kesatuan Republik Indonesia yang berdasarkan Pancasila dan UUD 1945 serta melindungi segenap bangsa dan seluruh tumpah darah Indonesia. Dalam mendukung tugas pokok TNI diperlukan suatu program pembinaan jasmani yang tersusun dengan baik sehingga menghasilkan suatu kondisi kebugaran tubuh yang selalu siap menjalankan tugas setiap saat. Kesehatan jasmani militer merupakan salah satu fungsi khusus TNI AD. Sesuai peran dan fungsinya menyelenggarakan pembentukan, peningkatan dan pemeliharaan jasmani militer baik perorangan maupun satuan, agar terwujud kesamaptaan jasmani yang diperlukan guna mendukung pelaksanaan tugas (Skep KSAD Nomor: Skep/350/X/2002).

Penyelenggaraan jasmani militer pada dasarnya harus dapat mewujudkan kesemaptaan jasmani yang diperlukan untuk mendukung tugas pokok TNI AD, oleh karena itu penyelenggaraan harus dilakukan secara konseptual dan proposional sehingga hasil penyelenggaraan dapat menyentuh dan bermanfaat bagi semua fungsi TNI AD dalam melaksanakan tugasnya secara berhasil guna dan berdaya guna. Latihan aerobik telah diketahui dapat menurunkan denyut nadi Istirahat. Fungsi dari keadaan denyut nadi yang rendah, berarti jantung dapat (Cooper, 2013) Artinya semakin rendah denyut nadi dalam keadaan istirahat maka semakin baik kesegaran jasmani yang dimiliki. 
Untuk mencapai kebugaran tubuh yang optimal diperlukan suatu program latihan yang tersusun dengan baik sehingga dapat diperoleh hasil yang diinginkan. Ada beberapa cara mengetahui kebugaran tubuh yang salah satu parameter pengukurannya yaitu dengan mengetahui volume oksigen maksimal (VO2 maks). (Sander et al., 2011), mengatakan bahwa kebugaran aerobik adalah kapasitas maksimal untuk menghirup, menyalurkan, dan menggunakan oksigen yang disebut VO2 maks. Pengukuran kebugaran dengan mengetahui VO2 maks dipandang sebagai cara yang paling baik dan dipercayai memiliki hubungan dengan kesehatan, prestasi kerja dan olah raga, semua ini berkaitan dengan daya tahan dan performa.

Kebugaran aerobik dipengaruhi oleh keturunan dan latihan, begitu juga seperti usia, jenis kelamin, dan lemak tubuh. Heriditer bertanggung jawab atas 25 hingga $40 \%$ dari perbedaan nilaii VO2 maks. (Sander et al., 2011), berpendapat bahwa lebih dari setengah perbedaan kekuatan maksimal aerobik dikarenakan oleh perbedaan genotype. Potensi untuk meningkatkan kebugaran aerobik dengan latihan memiliki keterbatasan, walaupun kebanyakan penelitian mengkonfirmasikan potensi untuk meningkat 15 hingga $25 \%$, dan hanya remaja saja yang memiliki harapan untuk meningkatkan kebugaran hingga lebih dari 30\%. Sebelum puber, anak laki-laki dan perempuan memiliki kebugaran aerobik yang sedikit berbeda, tapi setelah itu anak perempuan jauh tertinggal. Rata-rata wanita muda memiliki kebugaran aerobik antara 15 hingga 25\% lebih kecil dari pada pria muda. Sedangkan untuk usia terjadi penurunan 8 hingga 10\% per dekade untuk individu yang tidak aktif. Bagi yang aktif dapat menghentikan setengah dari penurunan tersebut (4 hingga 5\%), dan yang terlibat dalam latihan fitness dapat menghentikan setengahnya lagi (2,5\% per dekade).

Satu lagi faktor yang mempengaruhi kebugaran aerobik adalah aktivitas. Bahwa aktivitas yang kita lakukan secara reguler akan membentuk kesehatan, vitalitas, dan kualitas hidup. Pengaruh latihan bertahun-tahun dapat dapat hilang hanya dalam 12 minggu dengan menghentikan aktivitas. Istirahat ditempat tidur dapat menurunkan kebugaran 29\% atau 10\% per minggu (Sander et al., 2011).

Untuk itu diperlukan peningkatan kemampuan cadangan kerja (kebugaran jasmani) setiap prajurit dalam melakukan aktivitasnya sehari-hari agar selalu memiliki semangat kerja, kebugaran, kesungguhan, rasa tanggung jawab dan tanpa merasakan adanya kelelahan yang berarti dalam setiap melaksanakan tugasnya. Seperti apa yang dijelaskan oleh (Zmasek \& Eddy, 2001), Kesegaran Jasmani merupakan kesiapan dan kesanggupan seseorang untuk melakukan pekerjaan tertentu dengan baik tanpa mengalami suatu kelelahan yang berarti.

Olah raga dapat dibagi menjadi dua kelompok. Yang pertama adalah olah raga aerobik, yaitu olah raga yang menggunakan energi yang berasal dari pembakaran oksigen, dan membutuhkan oksigen tanpa menimbulkan hutang oksigen yang tidak terbayar. Contoh olah raga aerobik misalnya lari, jalan, treadmill, bersepeda, renang. Sedangkan olah raga anaerobik adalah olah raga yang menggunakan energi dari pembakaran tanpa oksigen, dalam hal ini aktivitas yang terjadi menimbulkan hutang 
oksigen. Contoh dari olah raga anaerobik adalah lari sprint jarak pendek, angkat beban, dan bersepeda cepat (Sukaningtyas, 2019).

Adapun tujuan dari pelaksanaan kegiatan ini adalah membentuk kesegaran jasmani prajurit Angkatan Darat, baik secara perorangan maupun dalam hubungan satuan, agar kondisi jasmani dalam keadaan siap dan memiliki daya tahan tubuh yang prima, sehingga mampu melaksanakan tugas dengan baik. Dengan demikian sasaran dari kegiatan latihan dapat tercapai, diantaranya: Terpenuhinya kebutuhan VO2 maks didalam tubuh seorang prajurit, terpeliharanya kerja jantung dan paru-paru sesuai dengan tuntutan kebutuhan, terciptanya daya tahan tubuh dalam menerima beban tugas yang berat, dan terpeliharanya kemampuan jasmani prajurit jajaran satuan Angkatan Darat sesuai standar ( Perkasad nomor/251/XII/2007 ).

Selama ini TNI AD telah melakukan kegiatan jasmani militer dengan bentuk latihan yang selama ini dilaksanakan seperti halang rintang, lintas medan dengan beban $5,5 \mathrm{~kg}$, kecepatan mars dengan beban 5,5 kg menempuh jarak $3 \mathrm{~km}$, dan ketahanan mars dengan beban $5,5 \mathrm{~kg}$. Yang pada dasarnya adalah latihan-latihan yang ditujukan untuk melatih dan meningkatkan kesegaran jasmani militer. Latihan-latihan tersebut diatas biasanya dilakukan secara rutin oleh para militer sebagai persiapan untuk tugas operasi seperti pengamanan perbatasan, atau operasi perdamaian sehingga tidak dilakukan setiap hari. Disamping itu ada beberapa bentuk latihan ketahanan dan kekuatan yang dilakukan di institusi TNI AD meliputi pull ups, sit ups, push up, shuttle run $6 \times 10$ meter. Adapun latihan aerobik dengan lari yang di kombinasi dengan membawa beban $5,5 \mathrm{~kg}$ belum dilakukan dalam latihan di institusi TNI AD.

\section{Metode Penelitian}

Penelitian ini adalah penelitian eksperimental dengan rancangan penelitian yang digunakan menurut (Bakta, 1997), adalah Randomized Pre Test and Post Test Group Control Design. Penelitian ini adalah penelitian eksperimental dengan rancangan penelitian yang digunakan menurut (Bakta, 1997), adalah Randomized Pre Test and Post Test Group Control Design.

Dalam penelitian ini sample dibagi menjadi 2 kelompok yaitu kelompok 1 berupa latihan lari selama 30 menit tanpa beban dan kelompok 2 berupa latihan lari selama 30 menit dengan beban. Semua kelompok diberi tes awal, kemudian diberikan perlakuan lima kali seminggu selama sepuluh minggu, selanjutnya masing-masing perlakukan diobservasi.

Data pada variable perubahan nilai VO2 maks didapatkan dari hasil pengukuran selisih nilai VO2 maks sesudah dan sebelum latihan. Pengukuran variable peningkatan VO2 maks dilakukan untuk meyakinkan penulis bahwa setelah latihan pembebanan pada kelompok perlakuan atau kelompok dua akan lebih bermakna apabila bibandingkan dengan kelompok 1 .

Penelitian ini menggunakan alat ukur Cooper Test yaitu dengan melakukan lari 12 menit diukur dengan stopwatch, diukur jarak yang telah di capai, selanjutnya dimasukkan dalam rumus : 


$$
\mathrm{VO}_{2} \max =\frac{d_{12}-505}{45}
$$

Keterangan : (1) $d_{12}$ adalah jarak yang telah ditempuh saat berlari selama 12 menit, (2) satuan untuk VO2 maks adalah $\mathrm{ml} / \mathrm{kg} /$ menit.

\section{Hasil dan Pembahasan}

\section{A. Hasil}

\section{Deskripsi Karakteristik Subjek}

Subjek dalam penelitian ini berasal dari Anggota Pusdikjas TNI AD Cimahi yang telah dilakukan assesmen, termasuk kriteria inklusif, dan bersedia mengikuti program latihan aerobik selama 10 minggu, terhitung mulai bulan Februari 2018 sampai dengan bulan April 2018. Pengambilan subjek dilakukan dengan cara peneliti datang ke Pusdikjas TNI AD Cimahi untuk mendapatkan subjek yang termasuk kriteria inklusif. Sampel diukur nilai nilai VO2 maks dengan melakukan test lari 12 menit kemudian dicatat sebagai data awal. Untuk mendapatkan sampel laki-laki usia 18 - 34 tahun sebanyak 34 orang mempunyai nilai kesegaran jasmaninya atau nilai VO2 maks nya kurang dari standar yang ditetapkan TNI AD sesuai dengan umur. Mempunyai postur tubuh dengan kriteria harmonis dan normal sesuai yang ditetapkan TNI AD.

Subjek diberikan program latihan dengan dua metode latihan aerobik yang berbeda. Pada Kelompok Perlakuan I diberikan pelatihan lari aerobik tanpa beban dan, Kelompok Perlakuan II diberikan pelatihan lari aerobik dengan beban masing-masing sebanyak 50 kali selama 10 minggu dan kemudian setelah latihan yang ke-50 dilakukan pengukuran nilai VO2 maks kembali dengan melakukan lari 12 menit untuk menentukan dan mencatat nilai akhir.

\section{Tabel 1}

Karakteristik Subjek Penelitian

Distribusi subjek menurut nilai awal VO2 maks

\begin{tabular}{ccccccc}
\hline \multirow{2}{*}{ Kategori } & \multicolumn{2}{c}{ Klp. Perlakuan I } & \multicolumn{2}{c}{ Klp. Perlakuan II } & \multicolumn{2}{c}{ Total } \\
\cline { 2 - 7 } & $\mathrm{N}$ & $\%$ & $\mathrm{~N}$ & $\%$ & $\mathrm{~N}$ & $\%$ \\
\hline Baik & 11 & $32,35 \%$ & 10 & $29,41 \%$ & 21 & $61,76 \%$ \\
Cukup & 4 & $11,76 \%$ & 5 & $14,70 \%$ & 9 & $26,47 \%$ \\
Sedang & 2 & $5,88 \%$ & 2 & $5,88 \%$ & 4 & $11,76 \%$ \\
Jumlah & 17 & $50 \%$ & 17 & $50 \%$ & 34 & $100 \%$ \\
\hline
\end{tabular}

Tabel 2

Karakteristik Subjek Penelitian

Distribusi subjek menurut postur tubuh

\begin{tabular}{ccccccc}
\hline \multirow{2}{*}{ Kategori } & \multicolumn{2}{c}{ Klp. Perlakuan I } & \multicolumn{2}{c}{ Klp. Perlakuan II } & \multicolumn{2}{c}{ Total } \\
\cline { 2 - 7 } & $\mathrm{N}$ & $\%$ & $\mathrm{~N}$ & $\%$ & $\mathrm{~N}$ & $\%$ \\
\hline Harmonis & 12 & $35,29 \%$ & 9 & $26,47 \%$ & 21 & $61,76 \%$ \\
Normal & 5 & $14,70 \%$ & 8 & $23,52 \%$ & 13 & $38,23 \%$ \\
Jumlah & 17 & $50 \%$ & 17 & $50 \%$ & 34 & $100 \%$ \\
\hline
\end{tabular}


Berdasarkan table 1, distribusi subjek menurut nilai awal VO2 maks pada Kelompok Perlakuan I (Latihan aerobik tanpa beban) menunjukkan subjek nilai kategori baik sebanyak 11 orang $(32,35 \%)$, nilai kategori cukup berjumlah 4 orang $(11,76 \%)$, dan subjek dengan kategori sedang sebanyak 2 orang $(5,88 \%)$ dengan jumlah seluruhnya 17 orang (50\%). Pada Kelompok Perlakuan II (Latihan aerobik dengan beban) menunjukkan subjek dengan kategori baik sebanya 10 orang $(29,41 \%)$, subjek nilai kategori cukup berjumlah 5 orang $(14,70 \%)$, dan dengan kategori sedang sebanyak 2 orang ( $5,88 \%$ ) dengan jumlah seluruhnya 17 orang (50\%.). Sehingga jumlah subjek dalam Kelompok Perlakuan I (Latihan aerobik tanpa beban) dan Kelompok Perlakuan II (Latihan aerobik dengan beban) berjumlah 34 orang (100\%).

Berdasarkan tabel 2, distribusi subjek menurut postur tubuh pada Kelompok Perlakuan I subjek dengan kriteria Harmonis berjumlah 12 orang $(35,29 \%)$, dan dengan kriteria Normal berjumlah 5 orang $(14,7 \%)$ sehingga berjumlah 17 orang (50\%). Pada Kelompok Perlakuan II subjek dengan kriteria Harmonis berjumlah 9 orang $(26,4 \%)$, dan dengan kriteria Normal berjumlah 8 orang $(23,52 \%)$ sehingga berjumlah 17 orang $(50 \%)$, sehingga jumlah subjek dalam Kelompok Perlakuan I dan Kelompok Perlakuan II berjumlah 34 orang (100\%). Dapat dilihat bahwa jumlah subjek dengan kriteria Harmonis lebih banyak pada Kelompok Perlakuan I. sedangkan pada Kelompok Perlakuan II hampir sama jumlah antara kriteria Harmonis dengan Normal.

Subjek diberikan program latihan dengan dua metode lari aerobik yang berbeda. Pada Kelompok Perlakuan I diberikan pelatihan metode Latihan aerobik tanpa Beban, dan Kelompok Perlakuan II diberikan pelatihan metode Latihan aerobik dengan Beban masing-masing sebanyak 50 kali selama 10 minggu dan kemudian sehari setelah latihan yang ke-50 dilakukan pengukuran nilai VO2 maks kembali dengan melakukan test lari 12 menit untuk menentukan dan mencatat data akhir.

\section{Lingkungan Penelitian}

Kondisi lingkungan selama pelatihan berdasarkan tempat/lapangan yang tersedia di Pusdikjas TNI AD di Cimahi sangat mendukung. Subjek penelitian sudah teradaptasi dengan lingkungan pelaksanaan pelatihan yang sekaligus sebagai tempat pendidikan sehari-hari, dengan demikian kondisi lingkungan tidak mempengaruhi pelaksanaan penelitian.

\section{Uji Persyaratan Analisis}

\section{a) Uji Normalitas dan Homogenitas Data}

Untuk menentukan uji statistik yang akan digunakan maka terlebih dahulu dilakukan uji normalitas dan homogenitas data hasil test pengukuran nilai VO2 maks sebelum dan sesudah pelatihan. Uji normalitas dengan menggunakan uji Saphiro Wilk, sedangkan uji homogenitas menggunakan Levene Test, yang hasilnya tertera pada Tabel 3. 
Tabel 3

Uji Normalitas dan Homogenitas data pada Kelompok Perlakuan I dan II

\begin{tabular}{|c|c|c|c|c|c|c|c|}
\hline \multirow{3}{*}{ Pelatihan } & \multicolumn{6}{|c|}{ Shapiro-Wilk Test } & \multirow{3}{*}{$\frac{\text { Levene's Tes }}{\mathrm{P}}$} \\
\hline & \multicolumn{3}{|c|}{ KLP I } & \multicolumn{3}{|c|}{ KLP II } & \\
\hline & Statistic & Df & $\mathrm{P}$ & Statistic & Df & $\mathrm{p}$ & \\
\hline Sebelum & 0,941 & 17 & 0,332 & 0,963 & 17 & 0,681 & \multirow{2}{*}{0,179} \\
\hline Sesudah & 0,951 & 17 & 0,471 & 0,941 & 17 & 0,333 & \\
\hline
\end{tabular}

Hasil uji normalitas (Saphiro Wilk-Test) nilai VO2 maks, bahwa sebelum pelatihan pada kelompok perlakuan I berdistribusi normal ( $\mathrm{p}>$ $0,05)$. Sesudah pelatihan pada kelompok perlakuan I berdistribusi normal ( $\mathrm{p}$ $>0,05)$. Pada kelompok perlakuan II sebelum dan sesudah pelatihan berdistribusi normal $(\mathrm{p}>0,05)$.

Hasil uji homogenitas (Levene-Test) menunjukkan kedua kelompok sebelum pelatihan nilai VO2 maks pada masing-masing kelompok menunjukkan $\mathrm{p}>0,05$, yang berarti nilai VO2 maks sebelum pelatihan adalah homogen.

Dari hasil pengujian normalitas tersebut, maka ditetapkan pengujian hipotesis sebagai berikut:

1) Uji Hipotesis I yaitu :

Pelatihan lari aerobik tanpa beban dapat meningkatkan kesegaran jasmani pada anggota militer Pusdikjas TNI AD di Cimahi. Pengujian hipotesis dengan menggunakan Paired Sample t-test.

2) Uji Hipotesis II yaitu:

Pelatihan lari aerobik dengan beban dapat meningkatkan kesegaran jasmani pada anggota militer TNI AD di Cimahi. Pengujian hipotesis dengan menggunakan Paired Sample t-test.

3) Uji Hipotesis III, yaitu:

Pelatihan lari aerobik dengan beban lebih efektif dari pada latihan lari aerobik tanpa beban dalam meningkatkan meningkatkan kesegaran jasmani pada anggota militer Pusdikjas TNI AD di Cimahi. Pengujian hipotesis dengan menggunakan Independent Sample Test.

b) Pengujian Hipotesis

\section{a) Uji Hipotesis I}

Berdasarkan Tabel 5.4 menunjukkan bahwa pada kelompok perlakuan I yaitu pelatihan Lari aerobik tanpa beban didapatkan nilai rerata VO2 maks sebelum pelatihan sebesar $(50,32 \pm 3,13) \mathrm{ml} / \mathrm{Kg}$ $\mathrm{BB} /$ menit dan sesudah pelatihan didapatkan nilai sebesar $(52,88 \pm 2,52)$ $\mathrm{ml} / \mathrm{Kg} \mathrm{BB} /$ menit. 
Tabel 4

Nilai rerata VO2 maks sebelum dan sesudah pada kelompok perlakuan I (latihan lari aerobik tanpa beban)

\begin{tabular}{|c|c|c|c|c|}
\hline \multirow[b]{2}{*}{$\begin{array}{c}\text { Kelompok } \\
\text { Data }\end{array}$} & \multicolumn{2}{|c|}{ Re-rata Nilai VO2 maks } & \multirow[b]{2}{*}{$\mathrm{t}$} & \multirow[b]{2}{*}{$\mathrm{p}$} \\
\hline & $\begin{array}{l}\text { Sebelum } \\
\text { perlakuan }\end{array}$ & $\begin{array}{l}\text { Sesudah } \\
\text { perlakuan }\end{array}$ & & \\
\hline Mean & 50,32 & 52,88 & -9306 & 0,0001 \\
\hline SD & 3,13 & 2,52 & $-9,500$ & 0,0001 \\
\hline
\end{tabular}

Dari hasil pengujian hipotesis dengan menggunakan uji Paired Sample t-test, maka didapatkan nilai $\mathrm{p}=0,0001,(\mathrm{p}<0,05)$.

Kesimpulannya: ada perbedaan yang bermakna nilai VO2 maks sebelum dan sesudah pelatihan lari aerobik tanpa beban. Yang berarti bahwa: Pelatihan lari aerobik tanpa beban dapat meningkatkan nilai VO2 maks.

b) Uji Hipotesis II:

\section{Tabel 5}

Nilai rerata VO2 maks sebelum dan sesudah pada kelompok perlakuan II (latihan lari aerobik dengan beban)

\begin{tabular}{|c|c|c|c|c|}
\hline \multirow{2}{*}{$\begin{array}{l}\text { Kelompok } \\
\text { Data }\end{array}$} & \multicolumn{2}{|c|}{ Re-rata Nilai VO2 maks } & \multirow[b]{2}{*}{$\mathrm{t}$} & \multirow[b]{2}{*}{$\mathrm{p}$} \\
\hline & $\begin{array}{l}\text { Sebelum } \\
\text { perlakuan }\end{array}$ & $\begin{array}{l}\text { Sesudah } \\
\text { perlakuan }\end{array}$ & & \\
\hline Mean & 50,60 & 53,81 & & 0,0001 \\
\hline $\mathrm{SD}$ & 3,62 & 3,36 & $-8,591$ & 0,0001 \\
\hline
\end{tabular}

Berdasarkan table 5 menunjukkan bahwa pada kelompok perlakuan II yaitu pelatihan lari aerobik dengan beban didapatkan nilai rerata VO2 maks sebelum pelatihan sebesar $(50,60 \pm 3,62)$ $\mathrm{ml} / \mathrm{KgBB} / \mathrm{menit}$ dan sesudah pelatihan didapatkan nilai sebesar $(53,81 \pm$ 3,36) $\mathrm{ml} / \mathrm{KgBB} / \mathrm{menit}$. Dari hasil pengujian hipotesis dengan menggunakan uji Paired Sample Test didapatkan nilai $\mathrm{p}<0,0001, \quad(\mathrm{p}<$ $0,05)$ yang berarti bahwa: Pelatihan lari aerobik dengan beban dapat meningkatkan nilai VO2 maks.

\section{c) Uji Hipotesis III:}

Sebelum melakukan uji hipotesis III, dilakukan uji homogenitas (Levene-Test) terlebih dahulu. Hasil uji menunjukkan kedua kelompok sebelum pelatihan dan sesudah pelatihan nilai $\mathrm{p}>0,05$, yang berarti kedua kelompok homogen. 
Tabel 6

Nilai rerata uji kompabilitas selisih nilai VO2 maks sesudah pelatihan antara kelompok I dan kelompok II

\begin{tabular}{cccccc}
\hline Kelompok & \multicolumn{2}{c}{ Re-rata Nilai VO2 maks } & & \\
\cline { 2 - 3 } Data & $\begin{array}{c}\text { Kelompok } \\
\text { I }\end{array}$ & $\begin{array}{c}\text { Kelompok } \\
\text { II }\end{array}$ & & $\mathrm{p}$ \\
& 2,56 & 1,13 & \multirow{2}{*}{1,376} & 0,179 \\
Mean & 2,51 & 1,57 & & 0,179 \\
SD & 3,21 & & &
\end{tabular}

Dari hasil pengujian hipotesis menggunakan Independent T-test untuk membandingkan perbedaan pengaruh menggunakan beban dan tanpa beban pada lari aerobik 12 menit terhadap peningkatan nilai VO2 maks (post test - post test) antara kelompok perlakuan (dengan beban) dan kelompok kontrol (tanpa beban) didapat hasil $\mathrm{p}=0,179(\mathrm{p}>0,05)$. Kesimpulannya adalah tidak ada perbedaan yang bermakna antara lari aerobik dengan beban dan tanpa beban terhadap peningkatan VO2 maks. Atau hal ini berarti pelatihan lari aerobik dengan beban tidak lebih efektif daripada lari aerobik tanpa beban dalam meningkatkan nilai VO2 maks pada anggota militer Pusdikjas TNI AD.

\section{B. Pembahasan}

\section{Kondisi subjek}

Subjek dalam penelitian ini berjumlah 32 orang, ditambah 2 orang sebagai cadangan, berasal dari anggota militer Pusdikjas TNI AD Cimahi yang telah diukur nilai VO2 maks dengan melakukan test lari 12 menit. Telah mendapatkan subjek laki-laki usia 18-34 tahun mempunyai nilai nilai VO2 maks kurang dari standar serta mempunyai postur tubuh dengan kriteria harmonis dan normal sesuai dengan yang ditetapkan TNI AD .

\section{Karakteristik Lingkungan Penelitian}

Tempat penelitian adalah dilapangan Pusdikjas TNI AD Cimahi , dimana suasana sangat mendukung pelaksanaan pelatihan, lapangan yang berbentuk lingkaran sudah dilengkapi tulisan setiap 20 meter, panjang lintasan 400 meter. Tempat pelatihan yang selalu dipakai untuk kegiatan latihan subjek sehari-hari.

Mengingat instruktur lapangan sering berada di tempat pengambilan data maka otomatis subjek sudah biasa terhadap lingkungan atau dengan kata lain lingkungan yang dipakai pengambilan data dan pada waktu pelatihan dalam keadaan familiar. Pelaksanaan penelitian yang selalu pagi hari memungkinkan subjek lebih siap melakukan latihan. Pelaksanaan latihan ini merupakan perintah pimpinan, dengan demikian subjek menjalankan kegiatan dengan semangat. Lingkungan yang nyaman memungkinkan subjek melakukan dengan sungguhsungguh sehingga subjek dapat menjalankan metode latihan maksimal dan dapat menghasilkan hasil latihan yang maksimal pula. 


\section{Distribusi dan Varians Subjek Penelitian}

Distribusi subjek penelitian Kelompok I dan II sebelum dan sesudah pelatihan, dilakukan uji normalitas dengan Shapiro-Wilk Test, sedangkan homogenitas varians antara kedua kelompok pelatihan diuji dengan Levene Test. Variabel yang diuji adalah nilai VO2 maks sebelum dan sesudah pelatihan pada masing-masing kelompok dan selisih nilai VO2 maks sebelum pelatihan dan sesudah pelatihan pada kedua kelompok. Hasil uji normalitas dan homogenitas untuk semua variabel tersebut menunjukan $p>0,05$ (tabel 3).

\section{Pelatihan lari aerobik dengan beban dan tanpa beban meningkatkan nilai} O2 maks.

Berdasarkan tabel 4 menunjukkan bahwa pada kelompok perlakuan I yaitu pelatihan lari aerobik tanpa beban didapatkan nilai rerata VO2 maks sebelum pelatihan sebesar $(50,32 \pm 3,13) \mathrm{ml} / \mathrm{KgBB} / \mathrm{menit}$ dan sesudah pelatihan didapatkan nilai sebesar $(52,88 \pm 2,52) \mathrm{ml} / \mathrm{KgBB} / \mathrm{menit}$. Dari data tersebut menunjukkan peningkatan nilai VO2 maks.

Berdasarkan tabel 5 menunjukkan bahwa pada kelompok perlakuan II yaitu pelatihan lari aerobik dengan beban didapatkan nilai rerata nilai VO2 maks sebelum pelatihan sebesar $(50,60 \pm 3,62)$ dan sesudah pelatihan didapatkan nilai sebesar $(53,81 \pm 3,36)$. Dari data tersebut menunjukkan peningkatan nilai VO2 maks yang diukur melalui tes lari 12 menit.

Dengan hasil ini dapat dikatakan bahwa pelatihan lari aerobik tanpa beban dan lari aerobik dengan beban yang diterapkan dapat meningkatkan nilai VO2 maks.

a) Peningkatan VO2 maks pada pelatihan lari aerobik tanpa beban.

(Kusmana, 2007), mengatakan, aerobik adalah setiap aktivitas fisik yang dapat memacu jantung dan peredaran darah serta pernafasan yang dilakukan dalam jangka waktu yang cukup lama sehingga menghasilkan perbaikan dan manfaat kepada tubuh.

Orang yang terlatih akan memiliki denyut jantung istirahat yang lebih rendah daripada orang biasa. Denyut jantung yang lebih rendah mengakibatkan nilai VO2max pada orang terlatih menjadi lebih tinggi. Denyut jantung dapat mengalami penurunan setelah melakukan latihan fisik selama waktu tertentu. Ini adalah kompensasi tubuh terhadap latihan fisik.

Tidak sama dengan latihan dalam jangka waktu yang pendek. Energi pada latihan dengan pemanasan diperoleh dari hasil proses oksidatif dari sumber makanan yang mulai muncul pada beberapa menit latihan dilakukan. Jumlah yang ditemukan dalam proses penyediaan energi dalam waktu lama dengan penggunaan oksigen dikenal dengan nama aerobik power. Penyediaan energi dalam latihan dengan pemanasan ini tergantung pada kesediaan oksigen dalam penggunaan kerja otot dalam waktu yang lama. Denyut nadi, frekwensi pernapasan, cardiac output, dan kebutuhan oksigen meningkat dalam latihan dalam waktu yang lama. 
Peningkatan nilai VO2 maks yang disebabkan dengan latihan terprogram juga dilaporkan sebelumnya oleh Adhikarma Uliyandri ( 2009 ), pada latihan fisik selama 12 minggu terhadap kelompok siswi usia $11-13$ tahun dan terjadi peningkatan yang signifikan.

Peningkatan frekwensi pernapasan akan meningkatkan jumlah oksigen dalam paru-paru yang akan meningkatkan proses difusi pada pembuluh darah. Peningkatan cardiac output akan meningkatkan jumlah darah yang ada pada pembuluh darah, akibatnya akan meningkatkan jumlah oksigen dalam otot. Dalam bagian penting peningkatkan cardiac output dapat diperoleh dengan adanya peningkatkan denyut nadi dan stroke volume. Perubahan stroke volume selama latihan relatif kecil, tapi salah satu keuntungan dari latihan adalah peningkatan stroke volume secara bermakna.

b) Peningkatan nilai VO2 maks pada pelatihan aerobik dengan beban.

Seperti yang disampaikan (Guyton \& Hall, 2007), latihan fisik atau olahraga dapat meningkatkan nilai VO2 maks. Akan tetapi peningkatan ini hanya terbatas sekitar 10-20\% dari nilai VO2 maks sebelumnya. Hal ini berkaitan dengan meningkatnya kerja sistem kardiovaskuler yang berupa peningkatan cardiac output, stroke volume, dan volume darah yang diikuti dengan menurunnya denyut jantung istirahat.

Menurut (Rattu, 1999) latihan beban yang dilakukan secara teratur dapat menghasilkan suatu respons terhadap kardiovaskuler yakni penurunan denyut nadi istirahat secara bermakna, tetapi tekanan darah istirahat tidak terjadi perubahan.

Bahkan (Rattu, 1999) juga mengatakan bahwa latihan beban yang dilakukan hanya dalam waktu 8 minggu 2 kali seminggu cukup dapat menimbulkan suatu adaptasi jantung paru terhadap latihan yang ditandai dengan penurunan denyut nadi istirahat yang bermakna.

Bila latihan beban dilakukan secara teratur dan disertai kebiasaan makan yang baik, berbagai sistem tubuh akan berubah secara positif. Otototot akan berubah lebih kuat dapat menimbulkan beban kerja yang lebih besar dan memperlihatkan berkurangnya rasa lelah dengan bertambahnya setiap masa latihan. Sistem neuromuskular akan berfungsi secara harmonis, karena otak akan belajar untuk menyeleksi serat-serat otot yang memiliki keperluan khas untuk melaksanakan berbagai beban, kecepatan gerak dan pola gerakan yang dibutuhkan dalam bermacam-macam latihan. Beberapa perubahan juga terjadi pada berbagai sistem tubuh (Baechle \& Earle, 1999).

Peningkatan nilai VO2 maks yang ditandai adanya penurunan nadi istirahat juga pernah dilaporkan oleh (Suhartini, n.d.) terhadap subjek wanita dengan melakukan program latihan dengan beban selama sepuluh minggu 3 kali seminggu terdapat penurunan yang bermakna.

Hasil yang sama juga dijumpai pada penelitian yang dilakukan oleh (Wilmore, Costill, \& Kenney, 1994) terjadi penurunan nadi istirahat setelah 
melakukan latihan aerobik selama 10 minggu. Mekanisme yang tepat dari latihan beban sehingga dapat menyebabkab penurunan nadi istirahat belum diketahui.tetapi ini kemungkinan oleh karena latihan menyebabkan terjadinya peningkatan aktivitas parasimpatis dan penurunan aktivitas simpatis dari jantung sehingga mengakibatkan denyut jantung menurun, vasodilatasi meningkat pada organ abdomen, aliran darah ke otot menurun, dan sekresi norepinefrin menurun sehingga denyut nadi dan tekanan darah juga menurun.

\section{Pelatihan lari aerobik dengan beban tidak lebih efektif daripada pelatihan lari aerobik tanpa beban dalam meningkatkan nilai VO2 maks.}

Dari nilai rerata peningkatan nilai VO2 maks Kelompok Perlakuan I dengan pelatihan lari aerobik tanpa beban $(2,56 \pm 1,13) \mathrm{ml} / \mathrm{KgBB} / \mathrm{menit}$ dan Kelompok Perlakuan II dengan pelatihan lari aerobik dengan beban sebesar $(3,21 \pm 1,57) \mathrm{ml} / \mathrm{KgBB} /$ menit menunjukkan bahwa tidak ada perbedaan peningkatan nilai VO2 maks antara Kelompok I dengan Kelompok II.

Pada Uji Hipotesis III, dimana :

Ho : Pelatihan lari aerobik dengan beban tidak lebih efektif daripada lari aerobik tanpa beban dalam meningkatkan nilai VO2 maks.

$\mathrm{Ha}$ : Pelatihan lari aerobik dengan beban lebih efektif daripada lari aerobik tanpa beban dalam meningkatkan nilai VO2 maks.

Dari hasil pengujian hipotesis dengan menggunakan Independent Test, didapatkan nilai $\mathrm{p}>(0,05)$ yang artinya Ho diterima, berarti pelatihan lari aerobik dengan beban tidak lebih efektif daripada lari aerobik tanpa beban dalam meningkatkan nilai VO2 maks.

Kenapa pelatihan lari aerobik dengan beban tidak lebih efektif dari pada pelatihan lari aerobik tanpa beban dalam meningkatkan nilai VO2 maks, mekanismenya adalah sebagai berikut :

a. Bahwa subjek merupakan orang-orang yang sudah biasa melakukan olah raga karena memang tuntutan pekerjaan.

b. Berdasarkan tabel 5.1 tergambarkan jumlah subjek dengan nilai awal kesegaran jasmani dengan kriteria baik lebih dominan dibandingkan dengan yang mempunyai kriteria cukup atau sedang. Hal ini memungkinkan terjadinya perubahan nilai VO2 maks hanya terjadi pada kelompok subjek dengan kriteria cukup atau sedang saja. Sedangkan pada subjek yang telah memiliki kriteria baik, tidak banyak mengalami perubahan.

c. Namun jika dilihat dari nilai rata-rata latihan aerobik dengan beban lebih baik peningkatan nilai rata-ratanya daripada latihan aerobik tanpa beban. Kemungkinan ini karena kelompok II lebih mengarah pada kerja latihan daya tahan anaerobik. Dilihat dari nilai rata-rata tersebut, maka latihan aerobik dengan beban lebih baik daripada latihan aerobik tanpa beban dalam peningkatan nilai VO2 maks. Hasil ini sesuai dengan hipotesis yang menyatakan bahwa latihan aerobik dengan beban lebih efektif untuk 
meningkatkan nilai VO2 maks dibandingkan dengan latihan aerobik tanpa beban.

Penggunaan beban 5,5 kg yang merupakan akumulasi berat rata-rata dari senapan dengan pakaian dinas lapangan (PDL) untuk subjek adalah hal yang biasa dikenakan terutama saat melaksanakan kegiatan kemampuan olah raga militer, seperti halang rintang, lintas medan, ketahanan mars. Akan tetapi kegiatan tersebut tidak setiap saat dilakukan, sehingga tidak setiap saat menggunakan beban tersebut dalam kesehariannya. Dengan demikian saat dilakukan penelitian pada kelompok perlakuan II ada selisih nilai VO2 maks apabila dibandingkan dengan kelompok perlakuan I.

\section{Kesimpulan}

Berdasarkan analisis penelitian yang telah dilakukan dan pembahasan dapat disimpulkan bahwa:

1. Latihan lari aerobik tanpa beban dapat meningkatkan nilai VO2 maks. Hal ini terlihat dari hasil uji hipotesis I yaitu dengan menggunakan uji Paired Sample ttest didapatkan nilai $\mathrm{p}<(0,05)$.

2. Latihan lari aerobik dengan beban dapat meningkatkan nilai VO2 maks. Hal ini ditunjukkan hasil uji hipotesis II yaitu menggunakan uji Paired Sample t- test, didapatkan nilai $\mathrm{p}<(0,05)$.

3. Latihan lari aerobik dengan beban tidak lebih efektif daripada Latihan lari aerobik tanpa beban dalam meningkatkan nilai VO2 maks. Terlihat dari hasil uji hipotesis III yaitu uji beda dua kelompok yang tidak berhubungan antara kelompok perlakuan I dengan kelompok perlakuan II dengan menggunakan uji Independent. Dari hasil pengujian didapatkan nilai $\mathrm{p}>(0,05)$.

4. Namun jika dilihat dari nilai rata-rata latihan aerobik dengan beban lebih baik peningkatan nilai rata-ratanya daripada latihan aerobik tanpa beban. Kemungkinan ini karena kelompok II lebih mengarah pada pengaruh overload dan progressive. 


\section{BIBLIOGRAFI}

Baechle, Thomas R., \& Earle, Roger W. (1999). Bugar dengan latihan beban. Raja Grafindo Persada.

Bakta, I. M. (1997). Diktat Mata Kuliah Metodelogi Penelitian. Denpasar: Program Studi Ergonomi Dan Fisiologi Olahraga Universitas Udayana.

Cooper, Kenneth H. (2013). Aerobics program for total well-being: Exercise, diet, and emotional balance. Bantam.

Guyton, Arthur C., \& Hall, John E. (2007). Buku ajar fisiologi kedokteran edisi 11. Jakarta: EGC, 81-85.

Kusmana, Dede. (2007). Olahraga Untuk Orang Sehat dan Penyakit Jantung. Edisi Kedua, Cetakan Ke-2 Tahun.

Kusnaendar, Dedy. (2018). Faktor-Faktor Pendorong Capaian Manajemen Mutu Terpadu Pada Smp Negeri 2 Sindang Rintisan Sekolah Bertaraf Internasional (Rsbi) Kabupaten Indramayu. Syntax Literate; Jurnal Ilmiah Indonesia, 3(2), 1-15.

Rattu, Angelheart Joy Maynard. (1999). Changes in resting heart rate and blood pressure in response to resistance exercise training program. Berkala Ilmu Kedokteran, 31(1999).

Sander, Janay B., Sharkey, Jill D., Groomes, Amber N., Krumholz, Lauren, Walker, Kimberly, \& Hsu, Julie Y. (2011). Social justice and juvenile offenders: Examples of fairness, respect, and access in education settings. Journal of Educational and Psychological Consultation, 21(4), 309-337.

Suhartini, Sri Mukti. (n.d.). Pengaruh Latihan Beban Terhadap Denyut Nadi Istirahat Dan Tekanan Darah Istirahat Pada Wanita Tidak Terlatih.

Sukaningtyas, Nuraini. (2019). Efektifitas Peer Guidance untuk Meningkatkan Efikasi Diri, Aktivitas dan Kedisiplinan Belajar Mandiri Siswa di SMP Hati BBS Kraksaan Probolinggo. Universitas Terbuka.

Wilmore, Jack H., Costill, David L., \& Kenney, W. Larry. (1994). Physiology of sport and exercise (Vol. 524). Human kinetics Champaign, IL.

Zmasek, Christian M., \& Eddy, Sean R. (2001). A simple algorithm to infer gene duplication and speciation events on a gene tree. Bioinformatics, 17(9), 821-828. 